\title{
Changes in the Lifestyle of Chinese Peasants over the Past 60 Years
}

\author{
Lijun Wang ${ }^{1,2}$ \\ ${ }^{1}$ School of Environment and Resources, Baoding University, Baoding 071000, China. \\ ${ }^{2}$ School of Environment, Beijing Normal University, Beijing 100875, China. \\ Received $29^{\text {th }}$ August 2013, Accepted 24 $4^{\text {th }}$ February, 2014, Published April 2014
}

\begin{abstract}
The lifestyles of Chinese peasants have changed remarkably since the foundation of the PRC. More than six decades addressed in this paper: from 1949 to today. The lifestyle of Chinese peasants has undergone revolution, politicization, collectivization, and urbanization with resulting synchronicity, imbalance, and disharmony. The first $\mathbf{3 0}$ years after the founding of the PRC, the material subsistence of Chinese peasants was severely deficient, but their spiritual life was rich. In the following $\mathbf{3 0}$ years, the reverse has been true: material living standards have significantly improved, but the spiritual life has markedly declined. In recent years, backward agricultural productive forces, small-scale land operation, a surplus of laborers, limited investment, weak infrastructure, and lack of agricultural modernization has resulted in three rural issues that is, agriculture, rural, and farmers issues. Resolving these issues is the utmost priority in the Party's work along with balancing urban and rural development, boosting rural development, working to narrow the gap between urban and rural areas and integrating urban and rural development provides the fundamental solution to these issues. With fewer restrictions over their economic activities and government support, the lifestyle of Chinese peasants is experiencing unprecedented and unforeseen vicissitudes.
\end{abstract}

Keywords: lifestyle; material lifestyle; spiritual lifestyle; new countryside development.

\section{INTRODUCTION}

Since the foundation of the PRC, changes in lifestyles of Chinese peasants continue to ubiquitous, and at times disconcerting. People from all walks of life talk about it, want it, oppose it, fear it, and, at times, even want to make sense out of it (Vago). They are exploring the nature underground, the change and the attitude towards it. Should the changes to the lifestyle of peasants since the founding of the PRC be seen as "warm or bitter memories"? These problems arouse severe controversy in academia, Chinese government circles, and civil society, so much, so that it is hard to reach consensus. There are many research results in this field. The famous scholar Fei Xiaotong, 2010 was not satisfied merely to reconstruct a static past, in his investigation of the traditional background of Chinese life. He grappled fully and deliberately with that most elusive and difficult phase of life: the transformation of traditional culture under Western impact (Xiaotong, 2010). The Chinese-American

E-mail: wljun1970@126.com; Tel: +8613730238973

Author(s) a gree that this artic le rema in permanently open access under the terms of the Creative Commons Attribution Lic ense 4.0 Intemational Lic ense 
scholar Huang (1986), focused on the agricultural involution characterized by "the law of diminishing productivity," because of population increase, which is called "Involutionary Theory." Those led to the peasants' standard of living hadn't been improved for long-term before the foundation of the PRC. Huang explained the reason systematically first time, attracted many scholarships to research further in this field. He pointed out that the production needs of peasants, who to some degree produced directly for household consumption, were accordingly shaped in part by considerations of household needs. Therefore, peasants' life was selfsufficient, lacking marketization. In this respect, the peasants were very different from their contemporaries who were urban residents, for whom the activities of production and consumption, of workplace and home, are generally distinct and separate. Peasants' life remained unchanged for long time. Huang (1990) probed the family and life in the Yangtze Delta of China from 1950 to 1980, people in the Yangtze Delta barely made enough of a living to feed their families in the face of collectivist and agricultural modernization. Since the 1980s, the living standard of the peasants has improved considerably. Rural industrialization has generated off-farm employment opportunities for peasants, as well as economic diversification, use of spare-time and auxiliary household labor for farming, and modern inputs like the use of chemical fertilizers. These changes have helped raise incomes significantly, have reversed involution, and have encouraged growth without the corresponding increases in time consumption that have occurred at other times (Huang, 1990). Huang only focused on changes in peasants' life being made by economic development, ignored social and policy change impact on it.

Since the foundation of the PRC, Chinese peasants have undergone revolution, politicization, collectivization, and urbanization, resulting in asynchronous, unbalanced, and disharmonious characteristics. Changes in the lifestyle of Chinese peasants have been epitomizing the impacts of social change and state's policy. During the first 30 years after the foundation of the PRC, the material subsistence of Chinese peasants was severely deficient, but their spiritual life was rich. During the following 30 years, after the implementation of the reforms, the reverse became true, with material living standards significantly improved but a marked decline in the people's spiritual life. This paper reviews the changes in lifestyle over the past 60 years, analyzing their characteristics, causes, and the historical experience, exploring the impacts of social change and state's policy besides economic factor.

\section{METHODOLOGY}

The historical comparative way has been applied fully in this paper, covers a span of over 60 years, 1949 to 2012: land reform, the agriculture cooperative movement, the great leap forward, the economic adjustment period, the cultural revolution, the beginning of reforms, the mid-late reforms, and the period since the sixteenth national congress of the CPC (post-2002), totaling eight periods that have characterized post-revolutionary development in China. In trying to understand the significance of historical data, the where, or spatial dimension, is often just as important as when. Thus, I have analyzed some of the events in relation to the geographical location where the events occurred.

This research is based on two sets of time-series data at the national as well as the provincial levels. Socio-economic data was analyzed from a number of different sources, including population, expenditure, revenue, consumption, and so on. These data were extracted from the following official government publications and other authoritative sources: China's Statistical Yearbook from 1959 to 2009 and some provincial Statistical Yearbooks at the same time. Statistical data did not record the changes in peasants lifestyle. I made some field visits and dictation interviews to investigate it

\section{RESULTS}

\section{The change phases of lifestyle in china Land Reform (1950-1952)}

Before liberation, especially during Japanese rule, the overwhelming majority of peasants could barely make a living, even without natural disasters, such as those arising from extreme weather. After the founding of the PRC, the CPC and the People's Government launched an unprecedented movement in land from 1950 to 1952, which reformed the system of feudal landlord land ownership and instituted peasant land ownership. The reforms were peaceful and orderly, carried out in accordance with the Land Reform Law formally promulgated in June 1950. Peasants with more than high end of the average amount of land were allowed to retain a little more than that, (this was called the "big average"); those at the low end of the range received a little less land, (the "small average"). In addition to land, the reform called for redistributing draft animals, farm implements, houses, and furniture; together with land, these were the so-called "five major properties" subject to redistribution.

Though implemented with little fanfare, this "peaceful" land reform wrought profound changes. It eradicated rent, equalized property differences, removed the basis for long-term wage labor, and set the stage for expanded state taxation. The equalizing of landholdings within the villages had comparatively little effect. But the impact of land reform was no less far-reaching, completely altering the villages' relations with their outside world. The villagers became owner-cultivators, pure and simple. Instead of rent payments to landlords, they now paid taxes to the state. For the peasants, state extraction and state power penetrated directly into villages for the first time in centuries. In terms of state-village power relations, land reform and expanded taxation brought state power into villages to an unprecedented degree. The old triangular relationship among state, gentry, and landlord, was replaced by a new bipolar relationship between state and 
peasants. Land reform and the new taxes represented the first steps in the massive penetration of state power into peasant's lifestyle and social contact.

Land reforms resulted in unprecedented historical change in China's rural areas. Three hundred million peasants without arable land obtained 700 million acres of arable land and other production means, relieving them from $350 \mathrm{Mt}$ (million ton) in grain tax (NBSC, 1959). The reform is the most significant and the largest revolution in the thousands years of Chinese history; it mobilized the masses and spurred peasants' enthusiasm for revolution and development, while liberating and developing agricultural productivity, and promoting the advancement of rural area society. From 1949 to 1952 , gross national farm production rose from 32.6 billion yuan to 48.4 billion yuan (48.5\%). Grain output increased by $113.2 \mathrm{Gt}$ to $163.9 \mathrm{Gt}$, and cotton production soared from $222.25 \mathrm{Mt}(92.9 \%)$. Output of other cash crops and animal products, such as eggs, milk, sugar, and liquor, also exceeded the highest levels in history (NBSC, 1959).

\section{Agriculture Cooperative Movement (1953-1956)}

After rural land reform, the average farmer possessed a mere $3 \mathrm{mu}$ (one mu equals to $666.67 \mathrm{~m}^{2}$ ) acres of arable land, while the average in the south of China was at the most $1 \mathrm{mu}$. Isolated, scattered, old-fashioned, and laggard small-scale farming constrained the development of agricultural productivity, national economic development, and industrialization. For example, from 1949 to 1957, China's cultivated land increased by about 200 million $\mathrm{mu}$, and the population increased by 200 million, so the average quantity of per capita cultivated land shrank 0.23 mu. Combined with the weak farming infrastructure and backward technology, natural disasters resulted in crop losses, causing a famine among 100 million peasants. Peasant poverty remained widespread (Runsheng, 2005). Therefore, the Chinese government launched the socialist transformation of agriculture in China, which consisted of three stages. In the first stage, on a voluntary basis and according to a mutually beneficial principle, agricultural mutual-aid teams were established, consisting of several families, up to slightly over 10 families. During the second stage, small agricultural production cooperatives were set up to combine farmers' capital, land, objectives, and labor so that the farmers would be shareholders in a jointly managed operation. In the third stage, the government organized peasants into large-scale agricultural production cooperatives based on socialist principles. These measures improved the peasants' socialist awareness and altered their lifestyle, step-by-step (En-Lai, 1957). In practice, it took only three years to accomplish socialist industrialization and socialist transformation. Peasant lost traditional family circle, began to enter social counterpart dominated by state.
Along with the agriculture cooperative movement followed the expansion of state control over commerce. On October 16, 1953, the Central Committee of the CPC adopted a resolution on the "Planned Purchase and Planned Sales of Grain," initiating the first of a series of important measures for bringing rural commerce under control. According to this resolution, serious shortages in the grain supply had developed, despite great advances in grain production. On the one hand, the demand for grain had increased with the expansion of the urban and industrial population and the improvement in living standards. On the other hand, the state had not been able to purchase what was needed because merchant and profiteers were hoarding grain in anticipation of scarcity and price rises. The party leaders therefore resolved that grain should be subject to unified purchase and unified sale. The resolution became official government policy with the State Council's "Commands on the Implementation of Planned Purchase and Planned Sale of Grain" of November 23, 1953 (ELSG, 1981).

The control of the grain trade was completed on August 25,1955 , with the State Council's passage of a set of "Provisional Regulations on Unified Purchase and Unified Sale of Grain in the Countryside," formally calling for quotas on each household's grain production (ELSG, 1981).

The fixing of compulsory purchase quotas, unified sale quotas, and production quotas together came to be known as the "three fixes in grain." The three fixes were implemented; there was no individual choice. Every household had to attend first to the state's procurement needs, and then to its own requirements for consumption, for feed, and for seeds (called the "three retains"). The policies did more than bring the household economy under control; they played a powerful role in pushing unwilling households into collectives.

The hasty formation of the agricultural cooperatives movement resulted in some problems, which were not rectified in time. Fortunately, the movement did not give rise to agricultural depression or uprisings. In this sense, the agricultural cooperatives movement was great success. In the first five-year plan, the total agriculture output value reached 60.4 billion yuan, at an annual average growth rate of $4.5 \%$; the total grain production reached $195 \mathrm{Mt}$ (growth rate $3.7 \%$ ); cotton production reached $1.64 \mathrm{Mt}$ (growth rate 4.7\%); and the production rate of other cash crops, livestock, poultry, meat, and eggs rose rapidly. Between 1952 and 1957, the agricultural tax remained unchanged, but agricultural product prices rose by $22.4 \%$ while industrial product prices rose by only $1.6 \%$ during the same term. Rural household income grew by 11 billion yuan: income levels saw a per capita increase of $27.9 \%$, while per capita consumption soared by $22.9 \%$. $20-30 \%$ of peasants lived affluently, $60 \%$ lived slightly above subsistence level, and 10 15\% lived below the subsistence level (En-Lai, 1957 and Gabriel, 1998). 
Table 1. State purchase grain quotas during 1958 to 1960 and percentage of grain output

\begin{tabular}{lccc}
\hline & $\mathbf{1 9 5 8}$ & $\mathbf{1 9 5 9}$ & $\mathbf{1 9 6 0}$ \\
\hline State purchase grain quotas (Mt) & 5.5 & 6.8 & 5.1 \\
Percentage of grain output (\%) & 27.3 & 39.6 & 35.7 \\
\hline
\end{tabular}

Note: Mt: million ton

\section{Great Leap Forward (1958-1962)}

From the winter of 1957 to the spring of 1958, the Farmland Water Conservancy and Manure Collection Projects were launched in the Chinese rural areas. Participants rose from 30 million in October, to 70 million in November, and to 80 million by December 1957, with the figure topping out at 100 million in January 1958. From this year, development in the Chinese countryside developed at a dramatic pace. In less than two months, 26,576 people's communes (accounting for 99.1\%) were established, 2.65 million public canteens opened up, 4.75 million nurseries and kindergartens, 100 thousand old folks' homes, and 25,577 militias. Meanwhile, the rural population was organized to participate in small-scale furnace steel making. The number of participants reached 50 million in September 60 million in October, and 90 million by November 1958 (Pinghan, 2003). Nearly the entire male labor force participated in steel making. Agricultural production was left to the old, sick, ill, disabled and women. The labor force deficiency, however, led to a sharp decline in crop production. The compulsory institutional change and social innovation included absolute egalitarianism and a work style characterized by boasting and exaggeration. It changed the traditional lifestyle completely.

Between 1959 and 1961, a combination of poor economic policies, succession of natural disasters, and widespread famine resulted in the deaths of 36.15 million people (Guohong, 1996). The Chinese government unilaterally emphasized steel production, unduly pursued industrial growth, and ignored agricultural production, along with people's life improvement. In this period, the industrial production value increased 2.3 times; however, agricultural production value dropped by $22.8 \%$. The agricultural labor decreased from 183.65 million people to 46.2 million people during 1957 and 1960. The land cultivation dropped $13 \%$, and grain output decreased to that of $1954(16.95 \mathrm{Mt})$, but state purchase quotas increased steadily (Table 1).

The dogma of the Great Leap forward-"the bigger the better," which even included pig farming - was concentrated under a single, commune-operated "factory." One problem immediately cropped up: the commune did not have access to the chaff from household consumption grain for feed. It tried burning cow dung for feed, but that did not work. Similarly, the commune could no longer rely on spare-time household labor for its compost, made by repeatedly adding grass to pig manure. The hog "factory" on its own was not able to generate more than minimal amounts of the organic fertilizer so vital to agriculture in this area. The makeshift pens finally collapsed under rain. Thus, the entire misguided enterprise was given up within few years.

The Chinese government has forbidden uncontrolled rural-urban migration since 1958 , which has prevented the vast rural population from inundating the cities, whose employment opportunities could not begin to match the population pressure in the countryside. Promulgated in January 1958, the Household Registration Regulations required every rural household to register with the collectives. Unauthorized changes of residence were strictly forbidden. The children of villagers had to follow the mother's registration, rather than the father's (Selected Public Security Laws and Regulations,1982). Peasants with little opportunity to leave the rural area for the city had to live in villages from the cradle to the grave.

\section{Economic Adjustment Period (1963-1965)}

The Great Leap forward led to severe economic depresssion, food shortages, and depopulation. In order to rectify the famine and the recessionary economy, the Tenth Plenary Session of the 8th CPC Central Committee passed "The Revised Draft Regulations on the Work of the Rural People's Commune," also referred to as the "60 Clauses on Agriculture." It regulated production teams as the basic organization and economic accounting unit and reformed three main fields, the first being the commune system. Workers were accredited with work points for the jobs they performed every day. At the end of a year the net team income, after deductions for state taxes, public welfare funds, and so on, was distributed according to the work points that each one had accumulated during the year (Lin, 1998). In 2005, Yao discussed the second field of reform which was the household responsibility system.

It was intended to restore the autonomy of the individual household and to replace the production team system as the unit of production and accounting in rural areas. The so-called responsibility contract was equivalent to the granting of private property rights through a state lease of land. Ownership was not relinquished by the state, but the rights to use and to obtain income were 
exclusively assigned to the lessee (Cheung, 1990). In fact, decision-making became significantly less centralized under the new system, and agricultural production started to recover in 1962 . The third reform addressed production team sizes, which relied on the amount of arable land and its accessibility, and labor force allocation in agricultural production. By October 1962, there were 71,551 people's communes, 713,385 production brigades and 5,468,244 production teams. Each commune administered an average of 9.6 production brigades, which, in turn, administered an average of 7.6 production teams, each of which consisted of 23.6 households, on average (Pinghan, 2003). Each commune was a selfsufficient unit, as were many of the brigades. The production team was the basic accounting unit, which was equivalent to a junior commune, which claimed most of the arable land and income. The institution promoted agricultural stability and production development.

In accordance with these regulations, the Chinese government at all levels gave priority to agriculture and rural development from 1961 to 1964, embarking on adjustment, consolidation, and substantial enhancement towards a balanced relationship between national economic and agricultural productivity. By 1965 , the per capita grain consumption, vegetable consumption, and income levels reached or exceeded those of 1957 (Pinghan, 2003). Peasant went back to traditional lifestyle in material life, but they were owing to has collectivism spirit to suffer to commend by leaders.

The famine was over by the end of 1962, and by 1965 , grain outputs had fully recovered to their pre-famine level (Yao, 2005). During this period, China's GDP increased by $40 \%$. Mao's call of "more people, more power" led to a peak birth rate during this period. As a result, population growth became a strong factor in China. In the meantime, the improvement in people's consumption levels significantly contributed to the population growth.

\section{Cultural Revolution (1966-1975)}

The Cultural Revolution was launched in 1966, soon after the country had recovered from the famine caused by the Leap Forward. The political campaigns that accompanied the Cultural Revolution were aimed mainly upward and outward from the villages. The work group from the upper levels was devoted to finding "corruption" in production teams or villages. Their main impact was on the cadres, not the peasants, and in the town, not the villages. Team cadres felt the shock waves first in the "four small cleans" movement in 1964. Some of them were disgruntled about the unjustness of the complaints against them, so did they. In the "four big cleans" the following year (1965), the target was not the cadres, but "class enemies." To attack them, a "mass organization," the Poor, LowerMiddle Association was established, with two representatives from each team. In the course of this campaign, the former "rich" were mistakenly fought against.

Despite the stormy experiences of the team cadres, however, there was little change of leadership at this level. Income distribution and household sidelines were untouched. The production team, the basic accounting unit that claimed most of the arable land and income, remained the same in the Cultural Revolution. The institution promoted agricultural stability and production development. However, both agricultural product average per capita and farmer per capita net income showed little improvement. For example, the grain average per capita was only $307 \mathrm{~kg}$ in 1976, about the same as that of 1956 . Farmer per capita net income from the production teams in 1978 was 70 yuan, and a quarter of a commune member's whole years' earnings was less than 50 yuan (Doje and Xu, 1999). Farmer households, production teams, and production brigades were confronted with difficulties in living and production. From 1954 to 1978, the average daily dietary intake of calories rose from $1985 \mathrm{Kcal}$ to $2215 \mathrm{Kcal}$ per person. The average daily dietary intake of fat rose from $26.3 \mathrm{~g}$ to $31 \mathrm{~g}$, and the average daily dietary intake of proteins rose from $51 \mathrm{~g}$ to $57.6 \mathrm{~g}$. Compared to normal nutritional needs, however, the intake of calories, fat, and protein fell short of the needed amount by $7 \%, 52 \%$, and $23 \%$ respectively (NBS, 1993). At the latter people's commune years, most peasants were sitting idle because of poor organization of work. Absolute egalitarianism in income distribution was severely imposed; therefore, both the farmers' enthusiasm and their income were very low. The farmers struggled to support themselves (Xinguang, 2003). At the time, although agricultural output tripled because of the increase in the agricultural population, the average peasant's income remained unchanged and even declined over the long term. Thus, the people's communes and production team were no guarantee of successful agricultural and rural development.

Despite their lack of the material means of subsistence during the people's commune period in China, the peasants' spiritual life appeared to be rich. At first, people's communes were different from rural villages in institution. They seemed to exceed the villages in terms of self-duplication, self-regeneration, and self-circulation, encapsulating a mechanism by which organized atomized individual households, lacking a spirit of cooperation, could be transformed into a small-scale economy that would set the farmers on the path to prosperity. This seemed to be the road of Chinese modernization that could narrow the gap between the rich and the poor. At that special time, ancient village and folk traditions and customs were severely criticized and remodeled. The government attempted to root out belief in spirits, ideals, cult worship, and illusions in an attempt to strengthen morality and order in the rural areas. Decentralized administration was replaced by unified collective production. Even with little prior experience, women participated in farm work like men. The production team implemented 
the principle by which men and women enjoyed equal pay for equal work. Selfish, easy-going, and desultory peasants were transformed into one with collective living, discipline, organization.

\section{The Beginning of Reforming and Opening-Up Year (1976-1988)}

After the economic reforms in 1978, China's economy went through a period of unprecedented growth. Between 1978 and 1984, the average per capita net income of rural residents rose from 133.57 yuan to 355.33 yuan, an annual growth rate of $17.71 \%$. Grain output rose from 30 Mt to $40 \mathrm{Mt}$, which created the miracle by which less than $7 \%$ of the world's cultivated farmland could feed $22 \%$ of world's population (Runsheng, 2005). From 1985 to 1988, the grain output rose and fell in successive years. However, the output value of township enterprises reached 200 billion yuan within a year, absorbing a 60million-strong work force to overcome the problem of a large population with relatively little arable land (Cheung, 1990). Between 1978 and 1988, the township enterprises became the fastest-growing section in the Chinese economy, accounting for one-third of industrial output. The peasants' income from townships was 382.8 billion yuan, which also accounted for $75 \%$ of net income (Jian, 2000). In addition, the government raised the procurement price of farm and sideline products, reducing the price agricultural production means and agricultural tax, optimizing the investment structure and continuously improving investment returns, safeguarding the sustainable growth of the incomes. For example, between 1979 and 1981, peasants' incomes rose to 5.2 billion yuan as a result of the booming procurement prices of farm and sideline products and agricultural remission (Jian, 2000). With the improvement in the material life, the spiritual life also was full of vigor and vitality.

Between 1984 and 1988, the rural economy developed rapidly, grain production soared substantially, and the number of township enterprises increased remarkably. Purchasing power also rose evidently. A large number of peasants moved into new flats. A family with a moderate income could afford to buy a bicycle, sewing machine, radio, watch, and some high-grade consumer goods. Previously, these had been too expensive for most families to afford. The rural market expanded. The rural surplus labor force was transferred to other economic sectors, promoting industrial development. Between 1978 and 1988 , the average per capita net income of rural residents rose from 134 yuan to 545 yuan, an annual growth of $11.8 \%$ on average, while the average per capita consumption by rural residents soared from 138 yuan to 508 yuan, averaging $9.7 \%$. Over the same period, the average per capita deposits of rural residents increased from 7 yuan to 138.7 yuan, but the ratio of urban and rural residents' income decreased from 2.37:1 in 1978 to $1.86: 1$ by 1985 . The ratio of urban and rural residents' consumption dropped from 2.9:1 in 1978 to 2.3:1 in 1986. Especially during the decade between 1978 and 1988, new home building reached 3.4 billion square meters in rural areas. That number was higher than the aggregate amount of construction during the 30 years before the implementation of the reform and opening-up policy as 75 of families built new houses. The average per capita living space increased from eight to 17 square meters (Jian, 2000). In addition, the peasants' diet diversified, the number of durable consumer goods owned by rural residents-like a radio, a bicycle, a sewing machine, a television, and a watch-increased considerably, and the farmers reaped the benefit from the optimization of their agricultural production resources, effected by improvements in the efficiency of agricultural production, the development in agricultural production, improvements in the farmers' living conditions, and an ensured supply of agricultural products.

The image of the farmer has undergone substantial change since the reform and the opening up of various policies. The peasants were no longer tied to the land. Off-farm work opportunities, superior salaries with benefits, and lighter working conditions enabled them live like urban residents. Women were no longer had to go barefoot or uncovered under the sun, as they were wellshod and completely protected from the sun under an umbrella. Thus, women no longer allowed their skin to darken like peasants from the past.

\section{Mid-Late Reforms and Opening Up (1989-2001)}

During 1989 to 2001, rural reform and development met with a certain degree of stagnation, which was considered typical of agriculture, the rural areas, and the peasantry. For example, from 1993 to 1994, the grain prices were adjusted by the market, but it was regulated by the government from 1997 to 1998. Grain prices continued to decline over the following seven years. Since a tax-sharing system reform was implemented in 1994, the financial revenue of counties and townships made up $21 \%$ of the state gross revenue, but provided for $71 \%$ of staff salaries. For example, for rural compulsory education expenditure, the central finance subsidized only $2 \%$, provincial finance contributed to $11 \%$, and county finance accounted for $9 \%$, township finance bearing the brunt of no less than $78 \%$ of total expenditure, leading to financial trouble for the townships. In addition, the percentage of funds for the development of aid-agriculture declined from $13 \%$ in 1985 to $8 \%$ by 2000 . With the progress of reform, increases in farmer per capita net income nonetheless showed a downward trend, increasing $4.6 \%, 4.3 \% 3.8 \%$, and $2.1 \%$, year by year, the increment being less than one-fifth that of urban residents (Xinguang, 2007). Most households' income fluctuated or even dropped. Rural social undertakings 
developed slowly, urban-rural development was unbalanced, and rural social contradictions were increasingly outstanding.

Since the mid-1980s, a flood of peasants had worked in cities as migrant workers, going through changes to their lifestyles because of unfamiliar surroundings. The number of migrant workers rose steadily from 2 million in the early stages of the reform and opening-up years, to 30 million by 1989 . Peasants left their land and their hometowns, but their social status remained unchanged. Since Deng Xiaoping's Southern Tour Speeches, China's economy began a new round of rapid growth, as did the rise in the number of migrant workers, up to 62 million by 1993, double that of 1989 (Changbin, 2007). The mainstream city culture changed their closed, monotonous, dull lifestyles to an open, rich, diverse, and civilized city lifestyle, and even going a step further to change the peasants' lifestyle completely. Migrant work lived city far away their family which led to family love weakens.

\section{Since the Sixteenth National Congress of the CPC (Post 2002)}

Issues concerning agriculture, countryside, and farmers ("three rural issues" for short) have become a bottleneck for social development during the comprehensive construction of the affluent society. Since the Sixteenth National Congress of the CPC, a series of measures that were put into effect concerning the harmonious countryside and new countryside development were actually all about resolving the three rural issues: Firstly, carrying out the strategy of development of agricultural sustainability, accelerating the construction of New Countryside. Between 2004 and 2009, the Party Central Committee issued Document No.1 of the Central Government for 6 consecutive years, which was aimed at raising peasants' income levels, improving agricultural integrated production capacity, and bringing about an advance in the rural economy. Furthermore, the document outlines strategies and the intention to accelerate agricultural modernization, and propel the urban-rural integration forward. The Eighteenth National Congress of the CPC promoted integrating urban and rural development to provide the fundamental solution to these issues (Jintao, 2012).

\section{DISCUSSION}

The paper focus on the changes in spiritual and material life of peasant, however, there are a lot of field to be investigated. The Eighteenth National Congress of the CPC promoted integrating urban and rural development to provide the fundamental solution to these issues. In striving to balance urban and rural development, boost rural development, narrow the gap between urban and rural areas, and promote their common prosperity, the government continues to encourage industry to support agriculture in return for the latter's earlier contribution to industrial development and to encourage cities to support rural areas, giving increasingly more to peasants. A spiritual lifestyle, such as public morality, professional ethics, family virtues, individual integrity, and traditional Chinese virtues, is being resumed and improved. Lifestyle of Chinese peasants is being confronted with unprecedented vicissitudes.

\section{CONCLUSIONS}

The lifestyle of Chinese peasants has changed remarkably over the last 60 years and has thereby undergone an asynchronous, unbalanced, and disharmonious process. In the 30 years after the foundation of the PRC, The material life of Chinese peasants was severely deficient, but their spiritual life was inspired, even through revolution, politicization, and collectivization. However, the following 30 years, after implementation of the reform and opening-up policies, the lifestyle of Chinese peasants went in the opposite direction, with significantly improved material living standards but a marked decline in their spiritual life. In particular, the household-responsibility system stimulated the peasants' production enthusiasm, and off-farm employment increased their income. These developments helped to produce substantially better crops. For the first time in centuries, incomes began to rise substantially above the margins of subsistence, which had not been possible under the collective system. However, backward agricultural productive forces, smallscale land operation, a surplus of laborers, limited investment, weak infrastructure, and lack of agricultural modernization resulted in the three rural issues.

\section{Conflict of Interests}

The author(s) have not declared any conflict of interests.

\section{REFERENCES}

Changbin Han (2007). The Development and End of Chinese Migrant Workers [M]. Beijing, China: China Renmin University Press.

Cheung SNS (1990). Privatization vs. Special Interestes: The Experience of China's Economic Reform, in James, A.D, Wang, X. (Eds.), Economic Reform in China: Problems and Prospects. University of Chicago Press, Chicago pp.21-37.

Doje Cering, Xu Songtao (1999). The Twenty-First Century: The Work of Villages and Towns. Beijing, China: China Agriculture Press.

Economic Law Study Group of Beijing Agricultural University \& Economic Law Teaching and Research Section Beijing Political Science and Law University. 1981. China's Agricultural Economic Legislation Compiled ( $8^{\text {th }}$ volume). Beijing, China: Beijing Agricultural University Press.

En-Lai Z (1957). Report on the Work of the Government. Beijing, China: People's China.

Gabriel SJ (1998). "The Structure of a Post-Revolutionary Economic Transformation: The Chinese Economy for the 1949 Revolution to the Great Leap Forward." China Essay Series. Mount Holyoke College. Retrieved March 18, 2013 (https://www.mtholyoke.edu/courses/ sgabriel/economics/china-essays/3.html). 
Guohong Z (1996). Man-Land Relationship. Shanghai, China: Fudan University Press.

Huang Philip CC (1986). The Peasant Economy and Social Change in North China. Stanford, CA: Stanford University Press.

Huang Philip CC (1990). The Household and Rural Development in the Yangtzi Delta, 1350-1988. Stanford, CA: Stanford University Press.

Jian S (2000). Chinese Economic History (Vol.3). Beijing, China: China Renmin University Press.

Jintao H (2012). Firmly March on the Path of Socialism with Chinese Characteristics and Strive to Complete the Building of a Moderately Prosperous Society in all Respects. Beijing, China: China Renmin Press.

Lin JY (1998). "The Household Responsibility System in China's Agricultural Reform: A Theoretical and Empirical Study." Econ. Deve. Cultural Change. 36:3199-224.

National Bureau of Statistical of China. (1993). China Yearbook of Household Survey (1992). Beijing, China: China Statistical Press.

National Bureau of Statistical of China.(NBSC) (1959). The Great Ten Years. Beijing, China: People's Press.

Pinghan Luo (2003). Rural People's Commune History. Fuzhou, China: Fujian People's Publishing House.

Runsheng Du (2005). China's Rural Reform Decision-making Record. Beijing, China: People's Press.

Selected Public Security Laws and Regulations of People's Republic of China. 1982. Beijing, China: Law Press, 8387.
Vago, Steven. Social Change. Beijing, China: Peking University Press. Xiaotong Fei (2010). Life in China: A Field Study of Country Life in the Yangtze Valley. Beijing: Foreign Language Teaching and Research Press.

Xiaotong Fei (2010). Peasant Life in China: A Field Study of Country Life in the Yangtze Valley. Beijing, China: Foreign Language Teaching and Research Press.

Xinguang Z (2003). "Study on the Whole Transition of Rural Land from Equal Distribution Mechanism to Market Economy Mechanism." J. Northwest Sci-Tech University of Agriculture and Forestry (Social Science Edition) 3(5):1-8.

Xinguang Z (2007). "The History Review: China's Rural Reform in Recent 30 Years." Modern Economic Research no. 1131.

Yao S (2005). Economic Growth, Income Distribution and Poverty Reduction in Contemporary China. London, UK: Routledge Curzon. 